
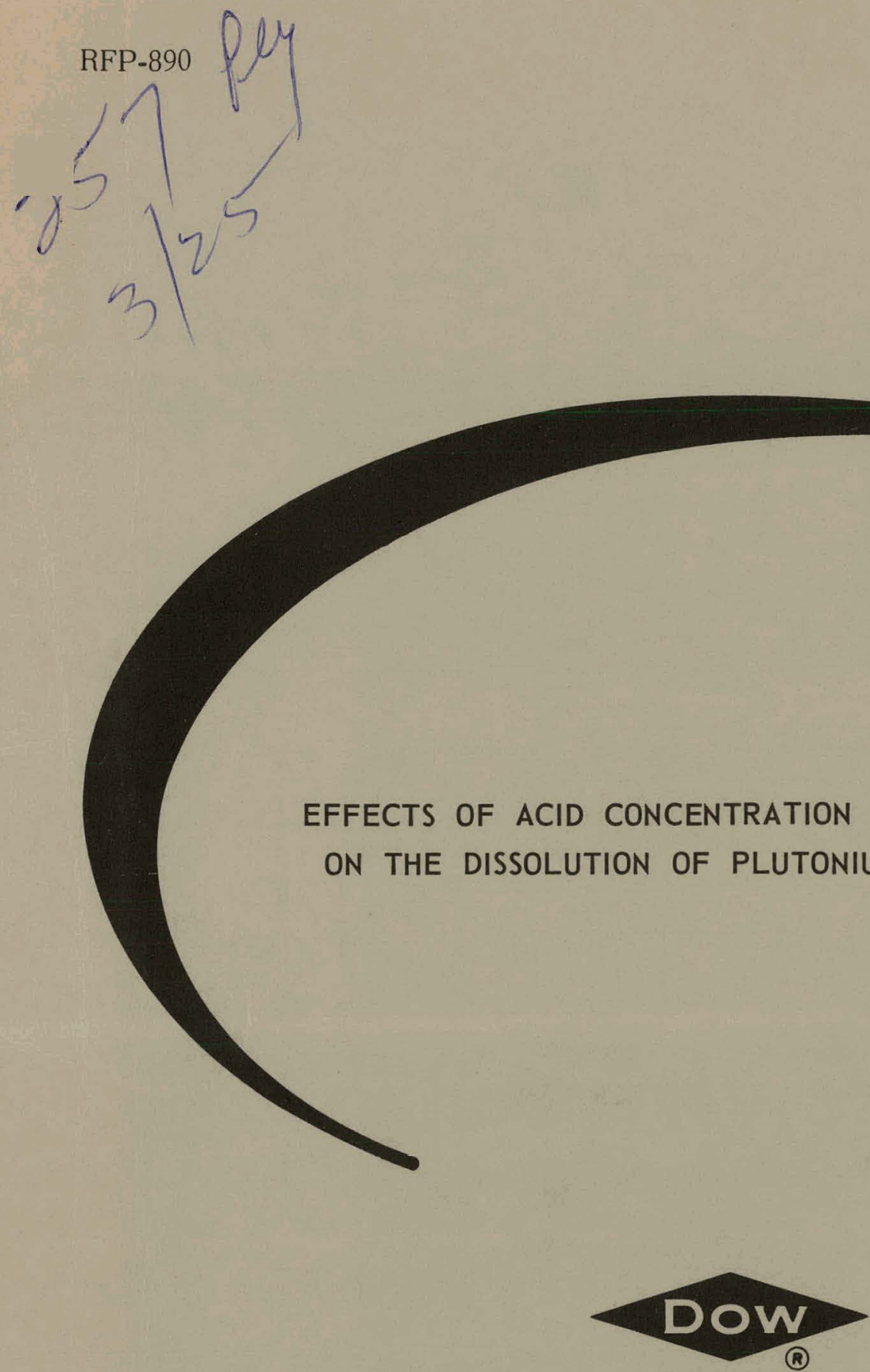

THE DOW CHEMICAL COMPANY ROCKY FLATS DIVISION

P. O. BOX 888

GOLDEN, COLORADO 80401

U.S. ATOMIC ENERGY COMMISSION CONTRACT AT(29-1)-1106 


\section{DISCLAIMER}

This report was prepared as an account of work sponsored by an agency of the United States Government. Neither the United States Government nor any agency Thereof, nor any of their employees, makes any warranty, express or implied, or assumes any legal liability or responsibility for the accuracy, completeness, or usefulness of any information, apparatus, product, or process disclosed, or represents that its use would not infringe privately owned rights. Reference herein to any specific commercial product, process, or service by trade name, trademark, manufacturer, or otherwise does not necessarily constitute or imply its endorsement, recommendation, or favoring by the United States Government or any agency thereof. The views and opinions of authors expressed herein do not necessarily state or reflect those of the United States Government or any agency thereof. 


\section{DISCLAIMER}

Portions of this document may be illegible in electronic image products. Images are produced from the best available original document. 


\section{LEGAL NOTICE}

This report was prepared as an account of Government sponsored work. Neither the United States, nor the Commission, nor any person acting on behalf of the Commission:

A. Makes any warranty or representation, expressed or implied, with respect to the accuracy, completeness, or usefulness of the information contained in this report, or that the use of any information, apparatus, method, or process disclosed in this report may not infringe privately owned rights; or

B. Assumes any liabilities with respect to the use of, or for damages resulting from the use of any information, apparatus, method, or process disclosed in this report.

As used in the above, "person acting on behalf of the Commission" includes any employee or contractor of the Commission, or employee of such contractor, to the extent that such employee or contractor of the Commission, or employee of such contractor prepares, disseminates, or provides access to, any information pursuant to his employment or contract with the Commission, or his employment with such contractor.

Printed in the United States of America

Available from

Clearinghouse for Federal Scientific and Technical Information

National Bureau of Standards, U. S. Department of Commerce

Springtield, Virginia 22151

Price: Printed Copy $\$ 3.00$; Microfiche $\$ 0.65$ 


\title{
EFFECTS OF ACID CONCENTRATION AND FEED-PARTICLE SIZE ON THE DISSOLUTION OF PLUTONIUM-BEARING MATERIALS
}

\author{
G. F. Molen
}

\footnotetext{
LEGAL NOTICE

NTI The United This report was prepared as an account of Government Bponsored work. Nolton: States, nor the Commission, nor any person action, expresied or implied, with respect to that the use

A. Makes any warranty or represental information contained in this report, or that ine inge

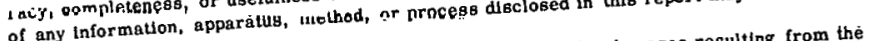
of any liformall owned rights; or

privately owned righ liabilties with respect to the use of, or for damaged report.

D. ABsumes any labillies wh respect o process disclosed In thls repart. ue of any information, apparatus, thethod,

As used in the above, "persan acting on boyee of such contractor, to the excent the po or contractor of the Combitssion, or emplo of employee of such contractor prepares, ployee or pes or contractor of the Commisslon, diseminates, or prouldes access to, any information pursuan.

whth the Commisoton. or his enploymen wh oud

\section{THE DOW CHEMICAL COMPANY .}

ROCKY FLATS DIVISION

P. O. BOX 888

GOLDEN, COLORADO 80401

U. S. ATOMIC ENERGY COMMISSION

CONTRACT AT(29-1)-1106
} 
RFP-890 


\section{CONTENTS}

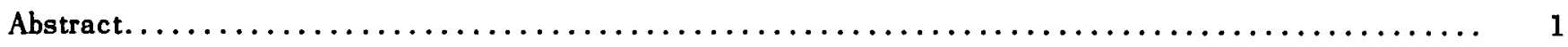

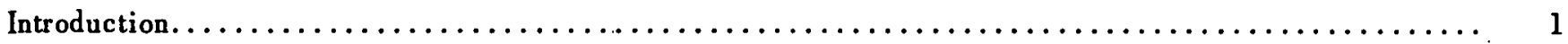

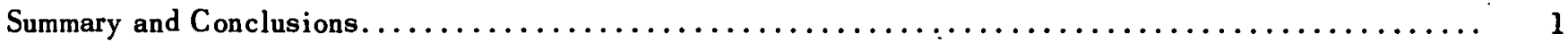

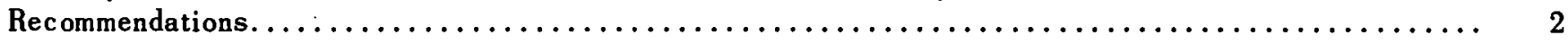

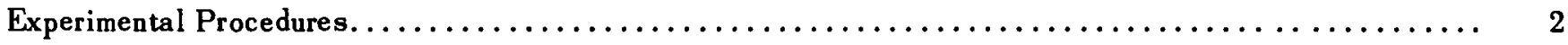

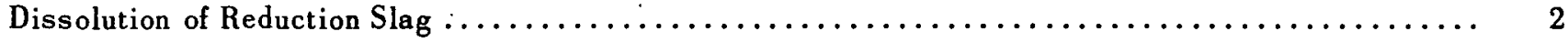

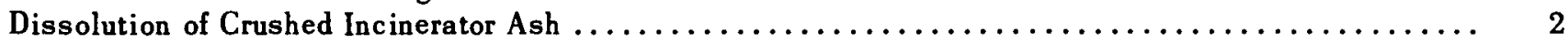

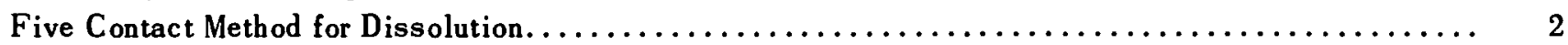

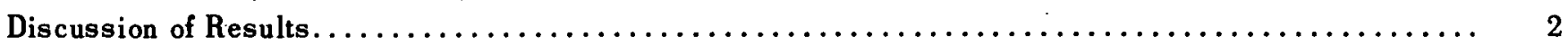

Effect of Acid Concentration on Dissolution of Reduction Slag . . . . . . . . . . . . . . . . .

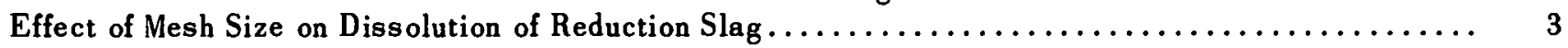

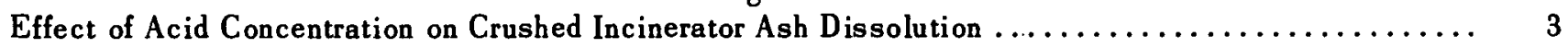

Reproducibility of Crushed Incinerator Ash Dissolution Results . . . . . . . . . . . . . . . . .

Effect of Initial Solid-to-Liquid Ratio Using the Five Contact Method for Dissolution ............. 4

Effect of Initial Feed Material Concentration Us ing the Five Contact Meth od for Dissolution ......... 7 


\section{ACKNOWLEDGMENT}

The author is indebted to E. J. Tomasi, A. D. Mills, and A. L. Johnston for performing the experimental work. I wish to thank L. F. Grill and W. S. Turnley for their cooperation. I also wish to thank N. E. Moody of the Plutonium Analytical Laboratory and his x-ray fluorescence and radioassay groups for performing the analyses required in this study. 
Effects of Acid Concentration and Feed-Particle Size on the Dissolution of Plutonium-Bearing.Materials

\author{
G. F. Molen
}

Abstract: The dissolution of plutonium-bearing residues in a nitric acid-calcium fluoride solvent system is described. The acid concentration, mesh size, initial solid-to-liquid ratio and initial feed material concentration arc evaluated in terms of the effects they have on the dissolution of these residues. The reproducibility of ash dissolution results is also measured.

\section{INTRODUCTION}

Many plutonium-bearing materials are generated as a result of producing, fabricating, and machining plutonium metal. These materials include incinerator ash (ash resulting from the incineration of plutonium contaminated burnables), glovebox floor sweepings (plutonium-c ontaining material that is inadvertently dropped on the floor of a glovebox), and reduction slag (slag resulting from the bomb reduction of $\mathrm{PuF}_{4}$ with calcium metal). To recover the plutonium, the plutonium-bearing materials are dissolved in nitric acid containing calcium fluoride. The plutonium-containing solution is purified by anion exchange. The material is often difficult to dissolve in this solvent system. The residue remaining after dissolution is called heel. Thus there are three types of plutonium-bearing heels which must be considered. They are incinerator ash heel, glovebox floor sweepings heel, and reduction slag heel.

In an earlier study ${ }^{1}$ the variables considcred were; the length of the reflux period, the drying temperature of heels, the solid-to-liquid ratio, the addition of fluoride during dissolution, and the effectiveness of a multiple contact system. The feed materials used for that study were crushed incinerator ash, incinerator ash heel, glovebox floor sweepings, and glovebox floor sweepings heel.

The purpose of this study was to determine the variables affecting the dissolution of the feed materials.

\footnotetext{
${ }^{1}$ G. F. Molen and R. O. Wing, "The dissolution of PlutoniumBearing Residues in a Nitric Acid-Calcium Fluoride Solvent. System," The Dow Chemical Company, Rocky Flats Division, RFP-776, November 22, 1966.
}

The feed materials used for this study were crushed reduction slag and crushed incinerator ash. The variables considered were the effects of acid concentration, feed-particle size, initial solid-to-liquid ratio, and initial feed material concentration.

\section{SUMMARY AND CONCLUSIONS}

The acid concentration, feed-particle size, reproducibility of results, initial solid-to-liquid ratio and initial feed material concentration were evaluated in terms of the effects they have on the dissolution of plutonium-bearing materials.

Two types of plutonium-bearing materials were used for feed. They were crushed reduction slag and crushed incinerator ash. The effect of nitric acid concentration between 3.0 and $15.0 \mathrm{M}$ on the dissolution of these materials was determined. The results showed that acid concentration had little effect on dissolution of crushed reduction slag. However, the dissolution of crushed incinerator ash was affected by acid concentration; maximum plutonium recovery was obtained when $9.0 \mathrm{M} \mathrm{HNO}_{3}$ was used.

The effect of feed-particle size on the dissolution of crushed reduction slag was evaluated by testing uns creened slag, >12-mesh slag, <12->18-mesh slag and $<18$-mesh slag. The results showed that the greatest plutonium recovery was obtained from small feed-particle sizes. Slag smaller than 35-mesh was too reactive to contain in the reaction vessel. Slag smaller than 18-mesh was considered best for dissolution.

The ability to reproduce incinerator ash dissolution results was measured by repeating a set of experiments five times.

The data for the acid concentrations showed a range of plutonium recovery from $68.2 \%-83.8 \%$ for $6.0 \mathrm{M} \mathrm{HNO}_{3}$ and from $54.3 \%-96.0 \%$ for $15.0 \mathrm{M} \mathrm{HNO}_{3}$. The results are not.considered reproducible, but average values do show a reproducible trend. This inability to reproduce results is undoubtedly because of the heterogeneous nature of crushed incinerator ash. 
A five contact method for dissolution was used to evaluate the effect of initial solid-to-liquid ratio and initial feed material concentration. The results showed that for an initial solid-to-liquid ratio greater than $75 \mathrm{~g} / \mathrm{l}$, four or more contacts were required for maximum plutonium recovery regardleșs of the initial feed material concentration.

\section{RECOMMENDATIONS}

The following recommendations from RFP-776 are still considered valid.

1. A multiple contact system consisting of three contacts is recommended. The first contact should be with "used" acid for one hour of refluxing; the second contact should be with fresh acid for a reflux period of 90 minutes; and the third contact should be with fresh acid for one hour of refluxing.

2. An initial solid-to-liquid ratio of $100 \mathrm{~g} / \mathrm{l}$ for the three contact system is recommended.

3. A calcium fluoride concentration of $0.2 \underline{M}$ for each contact is recommended.

4. The reflux period for each contact should not exceed 90 minutes.

5. The drying temperature of heels that have to be reprocessed should never exceed $650^{\circ} \mathrm{C}$.

The following recommendations are based on this study.

1. Nine molar nitric acid is recommended instead of twelve molar nitric acid.

2. If a multiple contacl system cannot be uscd, a solid-to-liquid ratio of $75 \mathrm{~g} / \mathrm{l}$ or less, for each dissolution cycle, is recommended.

3. It is recommended that, for any dissolution system, the initial solid-to-liquid ratio be decreased as the initial feed material concentration is increased.

4. When dissolving crushed reduction slag or any similar material, it is recommended that the particle size of the material be less than 18-mesh.

\section{EXPERIMENTAL PROCEDURES}

Dissolution of Reduction Slag: Crushed reduction slag ( $50.0 \mathrm{~g}$ ) was mixed with $500 \mathrm{ml}$ of nitric acid in a one-liter Florence flask of Pyrex glass which rested on a Thermolyne Stirplate that both heated and stirred (magnetically) the solution. The stirring speed (set on high) was held constant throughout all the experiments. Refluxing conditions $\left(110^{\circ}-115^{\circ} \mathrm{C}\right)$ were maintained for one hour by a water-cooled Liebig condenser. For reduction slags which contained large amounts of sand $\left(\mathrm{SiO}_{2}\right)$, the condenser had to be removed periodically and freed of the deposits of silic on dioxide formed by the hydrolysis of the volatile silic on tetrafluoride. At the end of the reflux period (one hour), the hot solution was filtered through a medium-porosity glass filter and the undissolved residue was washed with $200 \mathrm{ml}$ of $0.5 \mathrm{M} \mathrm{HNO}_{3}$. The undissolved residue was then air dried. The entire residue was accurately weighed, dried at $800^{\circ} \mathrm{C}$, reweighed, and analyzed for plutonium content by $x$-ray fluorescence. The filtrate volume was measured, sampled, and analyzed for plutonium by radioassay or $\mathrm{x}$-ray fluores cence.

Dissolution of Crushed Incinerator Ash: Crushed incinerator ash $(50.0 \mathrm{~g})$ was mixed with $500 \mathrm{ml}$ of nitric acid, containing $0.2 \mathrm{M} \mathrm{CaF}_{2}$, as described in the dissolution of reduction slag. All other procedures were the same.

Five Contact Method for Dissolution: Crushed incinerator ash was refluxed $\left(110^{\circ}-115^{\circ} \mathrm{C}\right)$ with 500 $\mathrm{ml}$ of $12 \mathrm{M} \mathrm{HNO}_{3}-0.2 \mathrm{M} \mathrm{CaF}_{2}$ for one-half hour. $\Lambda \mathrm{t}$ the end of the reflux period the hot solution was filtered, the filtrate volume measured, sampled, and analyzed for plutonium. The undissolved residue was quantitatively returned to the reaction flask. Five hundred milliliters of fresh $12 \mathrm{M} \mathrm{HNO}_{3}-0.2 \mathrm{M} \mathrm{CaF}_{2}$ were added and the solution was again refluxed for one-half hour. This procedure was repeated until five contacts of the original feed material had been made. After the fifth contact the solution was filtered and the filtrate volume was measured, sampled, and analyzed for plutonium content. The undissolved residue was air dried, accurately weighed, dried at $800^{\circ} \mathrm{C}$, reweighed, and the plutonium content determined by $\mathrm{x}$-ray fluorescence.

\section{DISCUSSION OF RESULTS}

Effect of Acid Concentration on Dissulution of Reduction Slag: The plutonium concentration in the 
feed material was held constant (1.5-1.8\% $\mathrm{Pu})$ and the nitric acid concentration was varied from $3 \mathrm{M}$ to $15 \mathrm{M}$ by intervals of three. The results, which are presented in Table I, show that the dissolution of unscreened reduction slag in nitric acid is little affected by the acid concentration. The average plutonium recoveries varied from $82.4 \%$ for $3 \mathrm{M} \mathrm{HNO}_{3}$ to $87.4 \%$ for $12 \underline{\mathrm{M}} \mathrm{HNO}_{3}$.

All undissolved residue concentrations (expressed in \% $\mathrm{Pu}$ ) were less than $0.7 \% \mathrm{Pu}$ which is the present discard level for material of this category. The solubility of slag was governed by the solubility of the major component, calcium fluoride. Under the experimental conditions used, the slag had a maximum solubility (in one hour) of $\sim 36 \mathrm{~g} / \mathrm{l}$ in $12 \mathrm{M} \mathrm{HNO}_{3}$.

Effect of Mesh Size on Dissolution of Reduction Slag: 'The crushed reduction slag was screened through Tyler equivalent 12- and 18-mesh sieves and divided into three fractions; greater than 12 mesh, less than 12 mesh but greater than 18 mesh, and less than 18 mesh. The different fractions were then dissolved as previously described. These results are tabulated in Table I. The plutonium concentration in the feed materials varied from $1.4 \%$ to $2.3 \%$.
The results show that for a given mesh size there was very little difference in plutonium recovery for various concentrations of acid. However, the results show a trend toward increasing plutonium recovery with decreasing mesh size because of the increased surface area. Reduction slag of 35 mesh was so reactive that it could not be contained in the dissolution vessel. This was due to both the heat of reaction and the small amounts of calcium metal which were present.

The data indicate that screening to less than 18mesh was best for plutonium recovery. Nine-tutwelve molar nitric acid is optimum for total solid solubility $(35-39 \mathrm{~g} / \mathrm{l})$. The solubility of reduction slag as a function of nitric acid concentration is shown in Figure 1.

Effect of Acid Concentration on Crushed Incinerator Ash Dissolution: The effects of acid concentration on the dissolution of crushed incinerator ash are summarized in Table II and Figure 2. The feed material averaged 5.3 to $5.9 \%$ plutonium. The acid concentrations used were $3.0,6.0,9.0,12.0$ and $15.0 \mathrm{M}$ $\mathrm{HNO}_{3}$. The results show that $9.0 \mathrm{M} \mathrm{HNO}_{3}$ is optimum for both total solid dissolution and plutonium recovery.

TABLE I. The Effect of Acid Concentration and Mesh Size on The Dissolution of Crushed Reduction Slag.

\begin{tabular}{|c|c|}
\hline $\begin{array}{l}\text { Nitric Acid } \\
\text { Conc. } \\
\text { (M) }\end{array}$ & $\begin{array}{c}\text { Sieve Size } \\
(\text { Mesh })^{a}\end{array}$ \\
\hline 3.0 & unscreened \\
\hline 6.0 & unscreened \\
\hline 9.0 & unscreened \\
\hline 12.0 & unscreened \\
\hline 13.0 & unscreened \\
\hline 3.0 & $>12$ \\
\hline 6.0 & $>12$ \\
\hline 9.0 & $>12$ \\
\hline 12.0 & $>12$ \\
\hline 15.0 & $>12$ \\
\hline 3.0 & $\langle 12\rangle_{18}$ \\
\hline 6.0 & $<12>18$ \\
\hline 9.0 & $\langle 12\rangle \mid 18$ \\
\hline 12.0 & $\langle 12\rangle \mid 8$ \\
\hline 15.0 & $\langle 12\rangle 18$ \\
\hline 3.0 & $<18$ \\
\hline 6.0 & $<18$ \\
\hline 9.0 & $<18$ \\
\hline 12.0 & $<18$ \\
\hline 15.0 & $<18$ \\
\hline
\end{tabular}

Solid-to-Liquid Ratio - $100 \mathrm{~g} / \mathrm{l}$, Reflux Period - One Hour

\begin{tabular}{c} 
Initial Feed \\
Conc. \\
(\% Pu) \\
\hline 1.5 \\
1.6 \\
1.6 \\
1.7 \\
1.8 \\
1.4 \\
2.3 \\
1.4 \\
1.5 \\
1.5 \\
1.6 \\
1.8 \\
1.6 \\
1.7 \\
1.7 \\
1.8 \\
1.5 \\
1.9 \\
1.8 \\
1.7
\end{tabular}

\begin{tabular}{c}
$\begin{array}{c}\text { Plutonium } \\
\text { Recovered } \\
\text { (\%) }\end{array}$ \\
\hline 82.4 \\
83.2 \\
83.5 \\
87.4 \\
84.1 \\
\\
88.7 \\
74.1 \\
86.4 \\
90.7 \\
87.1 \\
\\
87.6 \\
83.3 \\
88.1 \\
90.8 \\
89.0 \\
92.0 \\
92.8 \\
94.7 \\
94.6 \\
96.2
\end{tabular}

\begin{tabular}{c}
$\begin{array}{c}\text { Solid } \\
\text { Dissolved } \\
(\%)\end{array}$ \\
\hline 27 \\
32 \\
35 \\
36
\end{tabular}

Undissolved

Residue Conc. $(\% \mathrm{Pu})$

\begin{tabular}{l}
$\begin{array}{c}\text { No. of } \\
\text { Runs }\end{array}$ \\
\hline 3 \\
3 \\
3 \\
3 \\
3 \\
3 \\
3 \\
3 \\
3 \\
3 \\
3 \\
3 \\
3 \\
3 \\
3 \\
3 \\
3 \\
3 \\
3 \\
3 \\
3
\end{tabular}

a Tyler equivalent designations. 


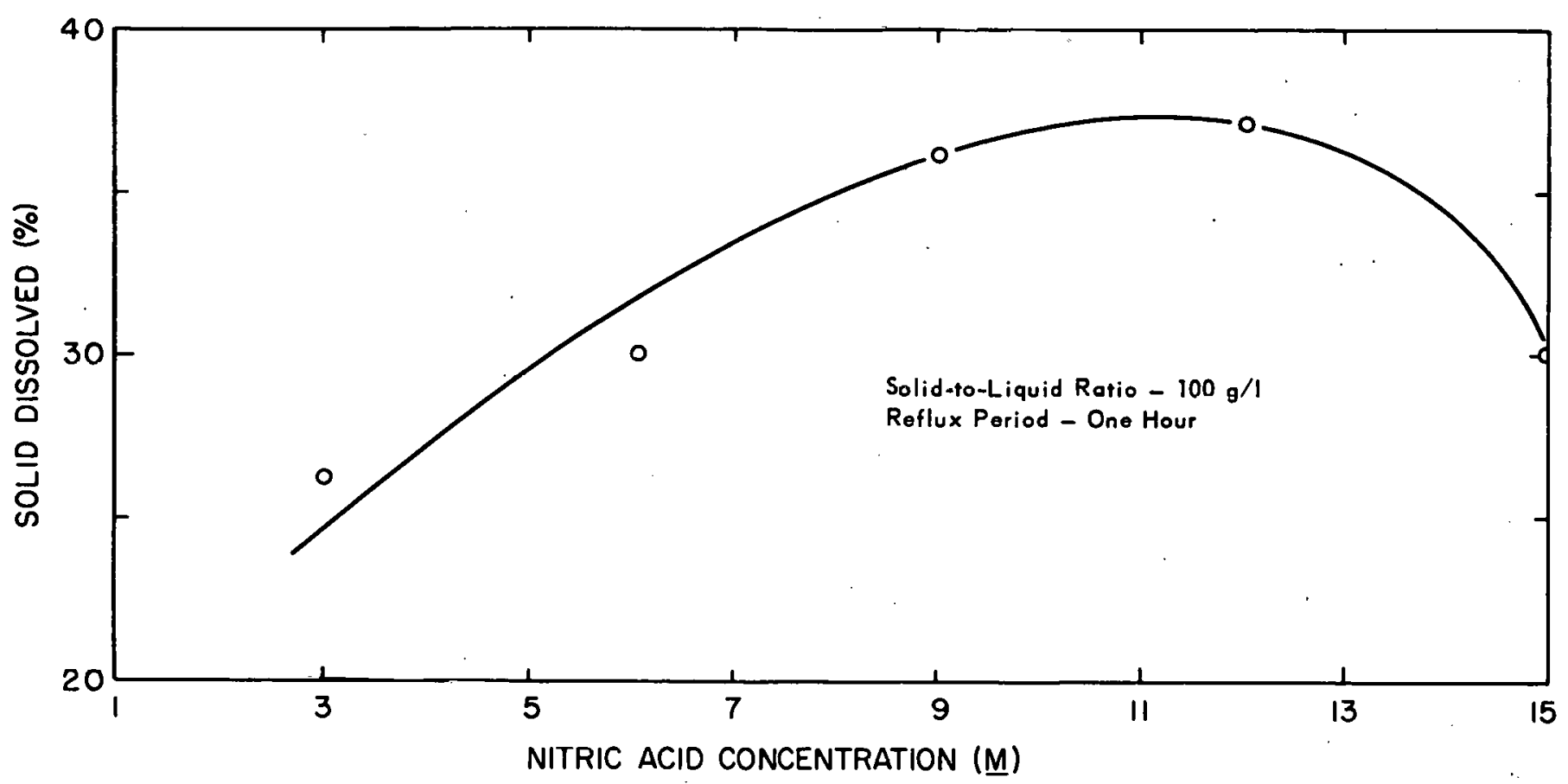

FIGURE 1. The Solubility of Crushed Reduction Slag as a Function of Nitric Acid Concentration.

TABLE II. The Effect of Nitric Acid Concentration on The Dissolution of Crushed Incinerator Ash. Solid-to-Liquid Ratio - $100 \mathrm{~g} / 1$, Reflux Period - One Hour, Calcium Fluoride Conc. - 0.2M

\begin{tabular}{c}
$\begin{array}{c}\text { Nitric Acid } \\
\text { Conc. } \\
(M)\end{array}$ \\
\hline 3.0 \\
6.0 \\
9.0 \\
12.0 \\
15.0
\end{tabular}

\begin{tabular}{c}
$\begin{array}{c}\text { Initial Feed } \\
\text { Conc. } \\
\text { (\% Pu) }\end{array}$ \\
\hline \\
\hline 5.5 \\
5.3 \\
5.9 \\
5.7 \\
5.8
\end{tabular}

\begin{tabular}{c}
$\begin{array}{c}\text { Plutonium } \\
\text { Recovered } \\
(\%)\end{array}$ \\
\hline 42.0 \\
75.9 \\
86.2 \\
81.3 \\
69.7
\end{tabular}

\begin{tabular}{c}
$\begin{array}{c}\text { Solid } \\
\text { Dissolved } \\
(\%)\end{array}$ \\
\hline \\
21 \\
34 \\
41 \\
35 \\
31
\end{tabular}

Reproducibility of Crushed Incinerator Ash Dissolution Results: A series of experiments was designed to determine the reproducibility of the dissolution results. Crushed incinerator ash was used and the procedure was the same as previously described. Each experiment was repeated five times (one of the samples for $6.0 \mathrm{M} \mathrm{HNO}_{3}$ was lost). The plutonium concentration in the feed material had a range of 4.8 to $6.5 \%$ with a minimum variation of $0.9 \% \Gamma u$ and a maximum variation of $1.5 \% \mathrm{Pu}$ for any given acid concentration. 'The results are shown in Table III. The plutonium recovered for a given acid concentration has a minimum variation of $15.6 \%$ for $6.0 \mathrm{M}$ and $9.0 \mathrm{M} \mathrm{HNO}_{3}$, and a maximum variation of $41.7 \%$ for
15.0M $\mathrm{HNO}_{3}$. The solid dissolved for a given acid concentration has a minimum variation of $7 \%$ for $12.0 \mathrm{M} \mathrm{HNO}_{3}$ and a maximum variation of $28 \%$ for 15.0M $\mathrm{HNO}_{3}$. From this information it is apparent that the dissolution results are not reproducible.

.This is due to the heterogene ous nature of the crushed incinerator ash. The average results of the dissolution behavior indicate that $9.0 \mathrm{M} \mathrm{HNO}$ is the optimum acid concentration.

Effect of Initial Solid-to-Liquid Ratio Using the Five Contact Method for Dissolution: The initial solid-toliquid ratio for these experiments was varied from 25 to $500 \mathrm{~g} / \mathrm{l}$ for feed material containing 11.5 to $13.9 \% \mathrm{Pu}$. 


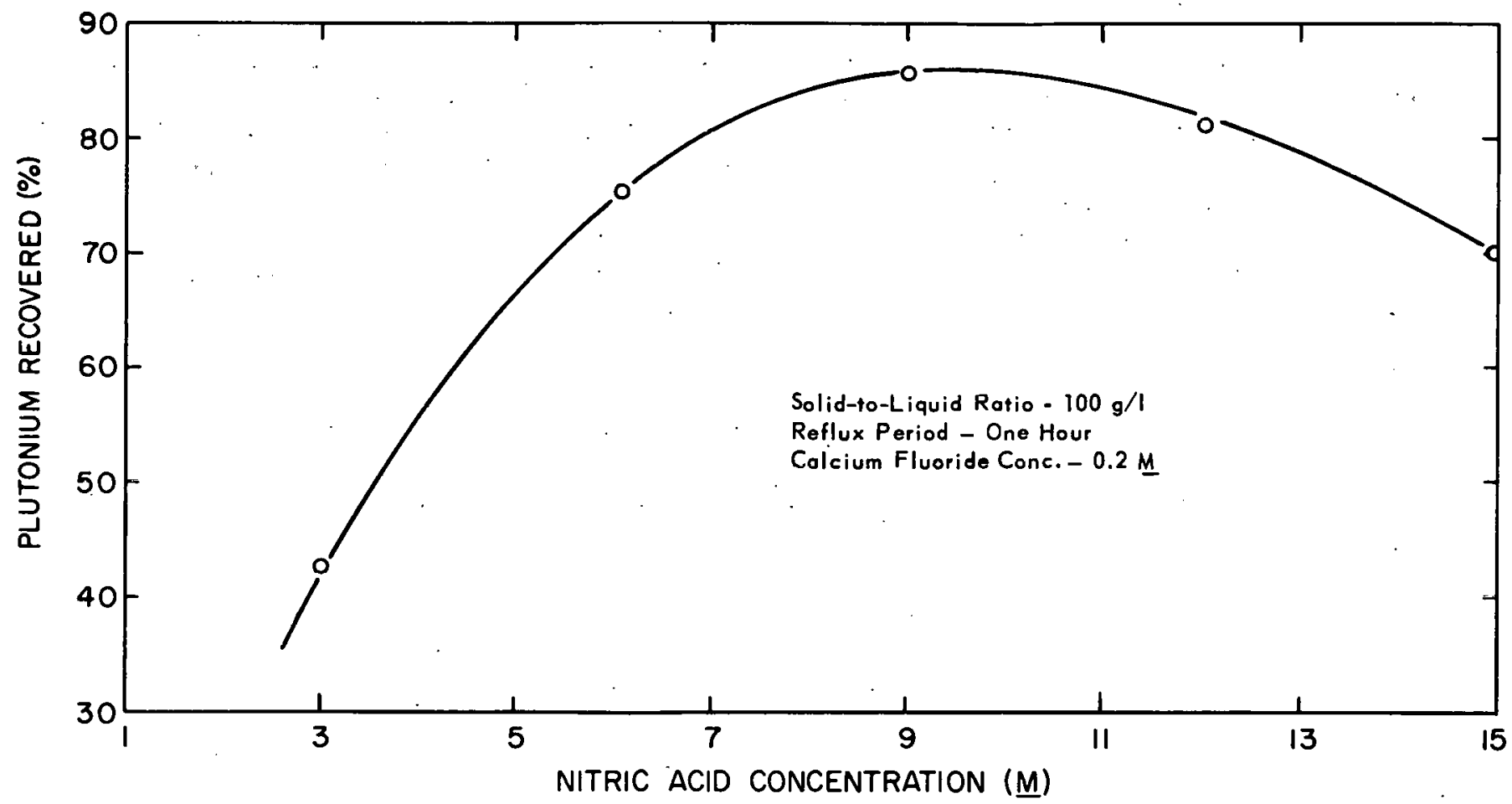

FIGURE 2. The Effect of Nitric Acid Concentration on the Dissolution of Incinerator Ash.

TABLE III. The Determination of the Ability to Reproduce Crushed Incinerator Ash Dissolution Results:

Solid-to-Liquid Ratio - $100 \mathrm{~g} / \mathrm{l}$, Reflux Period - One Hour, Calcium Fluoride Conc. - 0.2M

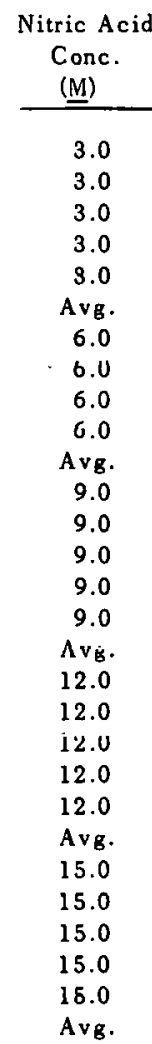

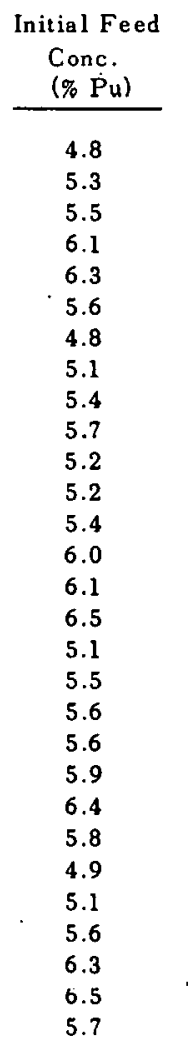

\begin{tabular}{c}
$\begin{array}{c}\text { Plutonium } \\
\text { Recovered } \\
(8)\end{array}$ \\
\hline 47.9 \\
\hline 25.0 \\
45.1 \\
32.3 \\
30.5 \\
36.2 \\
73.4 \\
68.2 \\
79.0 \\
83.8 \\
76.1 \\
79.1 \\
83.6 \\
94.7 \\
93.5 \\
79.2 \\
86.0 \\
70.8 \\
75.3 \\
77.4 \\
88.9 \\
93.1 \\
81.1 \\
63.3 \\
77.2 \\
54.3 \\
58.7 \\
96.0 \\
69.9
\end{tabular}

\begin{tabular}{c}
$\begin{array}{c}\text { Solid } \\
\text { Dissolved } \\
(\%)\end{array}$ \\
\hline 18 \\
\hline 18 \\
32 \\
18 \\
29 \\
29 \\
25 \\
38 \\
38 \\
36 \\
28 \\
35 \\
42 \\
41 \\
30 \\
34 \\
43 \\
38 \\
37 \\
30 \\
41 \\
34 \\
34 \\
37 \\
53 \\
57 \\
33 \\
31 \\
29 \\
41
\end{tabular}


The results are presented in Table IV. For the same plutonium concentration in the feed material ( $12-14 \%)$, an increase in the solid-to-liquid ratio from 25 to 500 $\mathrm{g} / \mathrm{l}$ decreases the percentage of plutonium recovered after one contact by $67 \%$. After two contacts the decrease is $44 \%$, and for the third, fourth and fifth contacts the decrease is $27 \%, 13 \%$, and $10 \%$ respectively. The decrease in plutonium recovery resulting from increasing the initial solid-to-liquid ratio can be minimized by increasing the number of contacts. The effect of the initial solid-to-liquid ratio on the total percent of dissolved solid after five contacts is illustrated in Figure 3. This curve shows that ratios greater than $75 \mathrm{~g} / \mathrm{l}$ result in a decreasing total percent of dissolved solid.

Table $V$ shows the data for the percent of remaining plutonium recovered per contact. The plutonium

TABLE IV. The Effect of the Solid-to-Liquid Ratio on the Cumulative Plutonium Recovered Using the Five Contact Method for the Dissolution of Crushed Incinerator Ash.

Reflux Period Per Contact - One-Half Hour, Feed Material - Crushed Incinerator Ash Calcium Fluoride Conc. - 0.2M per Contact, Nitric Acid Conc. - 12.5M Per Contact

\begin{tabular}{|c|c|c|c|c|c|c|c|c|c|}
\hline \multirow{2}{*}{$\begin{array}{c}\text { Initial } \\
\text { Solid-to- } \\
\text { Liquid } \\
\text { Ratio } \\
(\mathrm{g} / \mathrm{l})\end{array}$} & \multirow{2}{*}{$\begin{array}{c}\text { Initial } \\
\text { Feed } \\
\text { Material } \\
\text { Conc. } \\
(\% \mathrm{Pu}) \\
\end{array}$} & \multirow{2}{*}{$\begin{array}{l}\text { No. of } \\
\text { Runs }\end{array}$} & \multicolumn{5}{|c|}{ Cumulative Plutonium Recovered (\%) } & \multirow{2}{*}{$\begin{array}{c}\text { Solid } \\
\text { Dissolved } \\
(\%)\end{array}$} & \multirow{2}{*}{$\begin{array}{l}\text { Undissolved } \\
\text { Residue } \\
\text { Conc. } \\
\text { (\% Pu) }\end{array}$} \\
\hline & & & Cont. 1 & Cont. 2 & Cont. 3 & Cont. 4 & Cont. 5 & & \\
\hline 25 & 13.9 & 3 & 87.9 & 96.0 & 97.1 & 97.7 & 97.7 & 42 & 0.5 \\
\hline 50 & 13.2 & 3 & 69.2 & 90.4 & 94.6 & 96.8 & 98.2 & 58 & 1.0 \\
\hline 75 & 13.6 & 3 & 72.3 & 93.4 & 97.8 & 99.2 & 99.6 & 93 & 0.8 \\
\hline 100 & 13.1 & 3 & 60.2 & 89.0 & 96.5 & 99.2 & 99.8 & 85 & 0.2 \\
\hline 150 & 12.6 & 3 & 57.6 & 84.7 & 94.3 & 97.3 & 98.8 & 64 & 0.4 \\
\hline 200 & 11.6 & 3 & 40.5 & 63.3 & 80.5 & 84.6 & 87.4 & 57 & 3.4 \\
\hline 400 & 11.5 & 3 & 34.4 & 60.7 & 75.0 & 82.1 & 88.3 & 51 & 2.7 \\
\hline 500 & 12.2 & 3 & 27.3 & 53.9 & 70.9 & 84.8 & 87.4 & 46 & 2.8 \\
\hline
\end{tabular}

FIGURE 3. The Effect of tho Initial Solid-tn-T.iquid Ratio on the Total Percent of Dissolved Solid Using the Five Contact Method for the Dissolution of Crushed Incinerator Ash.

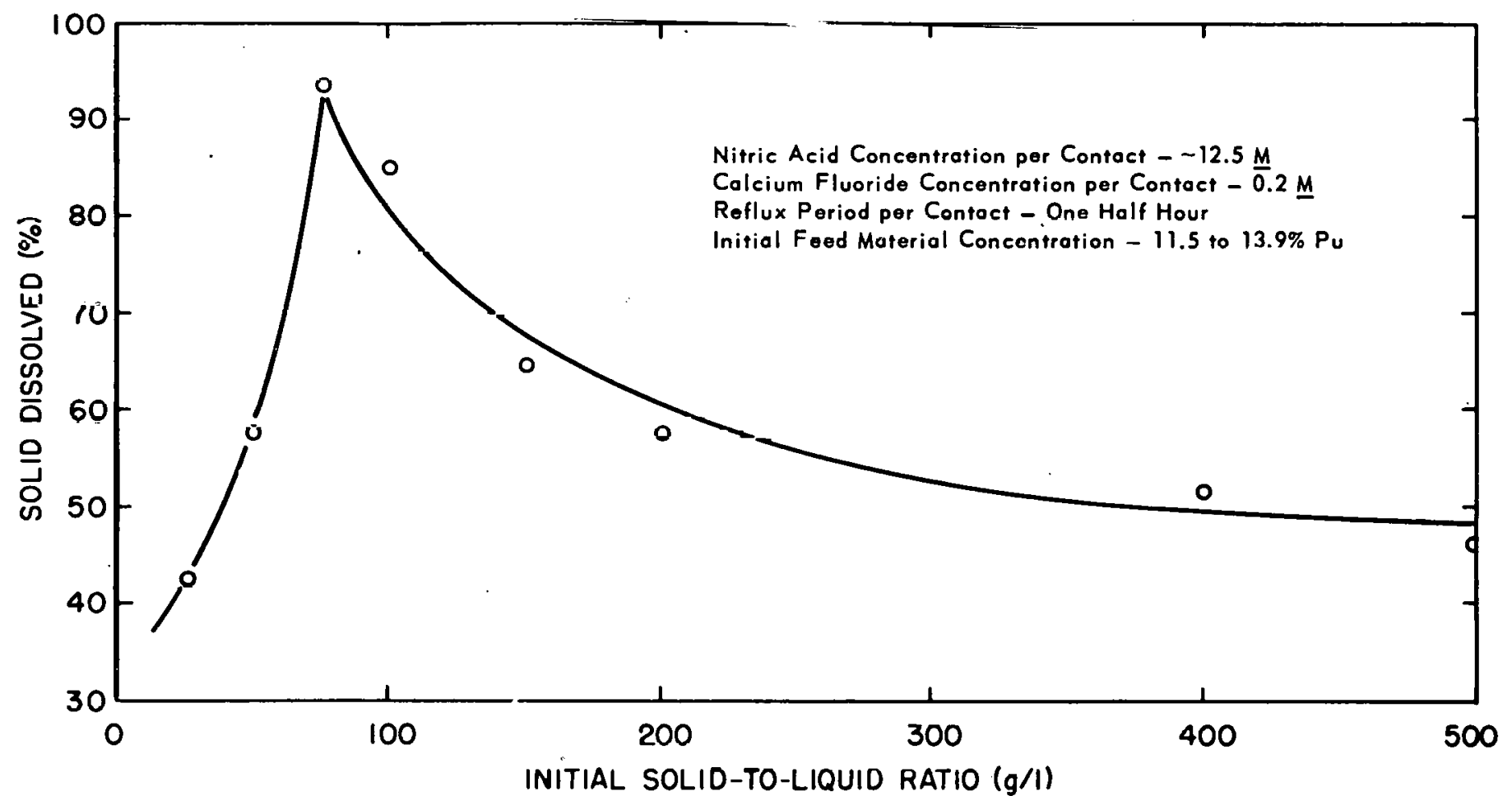


RFP-890

TABLE V. The Effect of Solid-to-Liquid Ratio on the Plutonium Recovered per Contact Using the Five Contact Method for the Dissolution of Crushed Incinerator Ash.

Reflux Period per Contact - One-Half Hour, Feed Material - Crushed Incinerator Ash Calcium Fluoride Conc. - 0.2M per Contact, Nitric Acid Conc. - 12.5M per Contact

\begin{tabular}{|c|c|c|c|c|c|c|c|}
\hline \multirow{2}{*}{$\begin{array}{l}\text { Initial } \\
\text { Solid-to- } \\
\text { Liquid } \\
\text { Ratio } \\
(\mathrm{g} / \mathrm{l})\end{array}$} & \multirow{2}{*}{$\begin{array}{c}\text { Initial } \\
\text { Feed } \\
\text { Material } \\
\text { Conc. } \\
(\% \mathrm{Pu})\end{array}$} & \multirow{2}{*}{$\begin{array}{c}\text { No. of } \\
\text { Runs }\end{array}$} & \multicolumn{4}{|c|}{ Plutonium Recovered (\%) per Contact } & \multirow[b]{2}{*}{ Contact 5} \\
\hline & & & Contact 1 & Contact 2 & Contact 3 & Contact 4 & \\
\hline 25 & 13.9 & 3 & 88 & 67 & 28 & 20 & 0 \\
\hline 50 & 13.2 & 3 & 69 & 70 & 46 & 34 & 40 \\
\hline 75 & 13.6 & 3 & 72 & 76 & 68 & 64 & 50 \\
\hline 100 & 13.1 & 3 & 60 & 72 & 68 & 78 & 80 \\
\hline 150 & 12.6 & 3 & 58 & 64 & 62 & 54 & 56 \\
\hline 200 & 11.6 & 3 & 40 & 38 & 47 & 21 & 18 \\
\hline 400 & 11.5 & 3 & 34 & 40 & 36 & 28 & 35 \\
\hline 500 & 12.2 & 3 & 27 & 36 & 37 & 48 & 17 \\
\hline
\end{tabular}

TABLE VI. The Effect of the Feed Material Concentration and the Solid-to-Liquid Ratio on the Cumulative Plutonium Recovered Using the Five Contact Method for Dissolution of Crushed Incinerator Ash.

Reflux Period - One-Half Hour per Contact, Feed Material - Crushed Incinerator Ash

Calcium Fluoride Conc. $-0.2 \mathrm{M}$ per Contact, Nitric Acid Conc. $-12.5 \mathrm{M}$ per Contact

\begin{tabular}{|c|c|c|c|c|c|c|c|c|c|}
\hline \multirow{2}{*}{$\begin{array}{l}\text { Initial } \\
\text { Solid-to- } \\
\text { Liquid } \\
\text { Ratio } \\
(\mathrm{g} / \mathrm{l}) \\
\end{array}$} & \multirow{2}{*}{$\begin{array}{l}\text { Initial } \\
\text { Feed } \\
\text { Material } \\
\text { Conc. } \\
(\% \mathrm{Pu}) \\
\end{array}$} & \multirow{2}{*}{$\begin{array}{c}\text { No. of } \\
\text { Runs }\end{array}$} & \multicolumn{5}{|c|}{ Cumulative Plutonium Recovered (\%) } & \multirow{2}{*}{$\begin{array}{c}\text { Solid } \\
\text { Dissolved } \\
(\%) \\
\end{array}$} & \multirow{2}{*}{$\begin{array}{c}\text { Undissolved } \\
\text { Residue } \\
\text { Conc. } \\
\text { (\% Pu) }\end{array}$} \\
\hline & & & Cont. 1 & Cont. 2 & Cont. 3 & Cont. 4 & Cont. 5 & & \\
\hline 25 & 13.9 & 3 & 87.9 & 96.0 & 97.1 & 97.7 & 97.7 & 42 & 0.5 \\
\hline 25 & 27.4 & 3 & 45.9 & 90.6 & 98.2 & 99.1 & 99.7 & 82 & 0.4 \\
\hline 50 & 10.2 & 3 & 64.4 & 87.1 & 92.2 & 96.1 & 98.4 & 34 & 0.2 \\
\hline .50 & 16.1 & 3 & 73.9 & 93.8 & 97.0 & 97.5 & 98.0 & 83 & 1.9 \\
\hline 75 & 13.6 & 3 & 72.3 & 93.4 & 97.8 & 99.2 & 99.6 & 93 & 0.8 \\
\hline 75 & 37.7 & 3 & 62.2 & 86.6 & 95.5 & 98.0 & 98.7 & 69 & 1.5 \\
\hline 100 & 5.7 & 3 & 53.2 & 71.8 & 83.8 & 90.8 & 95.4 & 83 & 1.5 \\
\hline 100 & 18.4 & 3 & 47.3 & 80.3 & 93.7 & 98.5 & 99.2 & 73 & 0.5 \\
\hline 200 & 4.5 & 3 & 40.7 & 69.9 & 77.4 & 84.5 & 90.3 & 76 & 1.8 \\
\hline 200 & 11.6 & 3 & 40.5 & 63.3 & 80.5 & 84.6 & 87.4 & 57 & 3.4 \\
\hline 400 & 6.2 & 3 & 42.6 & 63.4 & 7.4 .0 & 80.9 & 86.4 & 53 & 1.8 \\
\hline 400 & 11.5 & 3 & 34.4 & 60.7 & 75.0 & 82.1 & 88.3 & 51 & 2.7 \\
\hline
\end{tabular}

recovered per contact for a given solid-to-liquid ratio does not follow a pattern. The optimum number of contacts is defined as that contact number in which the plutonium recovery is maximum. The data show that a different number of contacts is optimum for different solid-to-liquid ratios. The data for ratios from $150-500 \mathrm{~g} / \mathrm{l}$ is too erratic to establish the optimum number of contacts. Probably the optimum number of contacts for ratios greater than $150 \mathrm{~g} / \mathrm{l}$ is greater than five.

Effect of Initial Fced Material Cuncentration Using the Five Contact Method for Dissolution: The effects of the plutonium concentration in the feed material and the initial solid-to-liquid ratio on plutonium recovery are tabulated in Table VI. These results show that the plutonium concentration in the feed material for solid-to-liquid ratios of 25 tn $100 \mathrm{~g} / 1$ is not as important as the solid-to-liquid ratio unless the initial feed concentration is greater than $20 \%$ plutonium. For solid-to-liquid ratios $\geq 200 \mathrm{~g} / \mathrm{l}$ the plutonium concentration in the feed material is not as important as the solid-to-liquid ratio.

Tabulating (see Table VII) the amount of remaining plutonium recovered per contact for these same 
experiments shows the optimum number of contacts required as a function of solid-to-liquid ratio and feed material concentrations.

The general trends indicated by the results of these experiments are presented in Table VIII. These values may be used as guidelines in determining optimum conditions (i.e. solid-to-liquid ratio and number of contacts for a given plutonium concentration in the feed material) for dissolving crushed incinerator ash. These numbers are not meant to be absolute and variations to this behavior are to be expected.

TABLE VII. The Effect of the Feed Material Concentration and the Solid-to-Liquid Ratio on the Plutonium Recovered per Contact Using the Five Contact Method for Dissolution of Crushed Incinerator Ash.

Reflux Period - One-Half Hour per Contact, Feed Material - Crushed Incinerator Ash

Calcium Fluoride Conc. - 0.2M per Contact, Nitric Acid Conc. - 12.5 M per Contact

\begin{tabular}{l} 
Initial \\
Solid-to- \\
Liquid \\
Ratio \\
$(\mathrm{g} / \mathrm{l})$ \\
\hline \\
25 \\
25 \\
50 \\
50 \\
75 \\
75 \\
100 \\
100 \\
200 \\
200 \\
400 \\
400
\end{tabular}

\begin{tabular}{|c|c|}
\hline \multicolumn{2}{|l|}{$\begin{array}{l}\text { Initial } \\
\text { Feed }\end{array}$} \\
\hline & \\
\hline $\begin{array}{l}\text { Conc. } \\
(\% \mathrm{Pu})\end{array}$ & $\begin{array}{l}\text { No. of } \\
\text { Runs }\end{array}$ \\
\hline 13.9 & 3 \\
\hline 27.4 & 3 \\
\hline 10.2 & 3 \\
\hline 16.1 & 3 \\
\hline 13.6 & 3 \\
\hline 37.7 & 3 \\
\hline 5.7 & 3 \\
\hline 18.4 & 3 \\
\hline 4.5 & .3 \\
\hline 11.6 & 3 \\
\hline$\cdot 6.2$ & 3 \\
\hline 11.5 & 3 \\
\hline
\end{tabular}

Plutonium Recovered per Contact (\%)

\begin{tabular}{|c|c|c|c|c|c|}
\hline Runs & Contact 1 & Contact 2 & Cuniacl 3 & Guntact 4 & Contage 5 \\
\hline 3 & 88 & 67 & 28 & 20 & 0 \\
\hline 3 & 46 & 83 & 81 & 50 & 67 \\
\hline 3 & 64 & 64 & 39 & 50 & 60 \\
\hline 3 & 74 & 76 & 52 & 17 & 20 \\
\hline 3 & 72 & 76 & 68 & 64 & 50 \\
\hline 3 & 62 & 64 & 66 & 56 & 36 \\
\hline 3 & 53 & 40 & 42 & 43 & 50 \\
\hline 3 & 47 & 63 & 68 & 76 & 50 \\
\hline 3 & 41 & 49 & 25 & 31 & 37 \\
\hline 3 & 40 & 38 & 47 & 21 & 18 \\
\hline 3 & 43 & 36 & 29. & 25 & 28 \\
\hline 3 & 34 & 40 & 36 & 28 & 35 \\
\hline
\end{tabular}

TABLE VIII. The Recommended Number of Contacts for the Dissolution of Crushed Incinératot Ash as a Function of the Initial Feed Material Concentration and the Initial Solid-to-Liquid Ratio.

Initial Feed Material Concentration (\% Pu)
Initial Solid to Liquid Ratio (g/l)

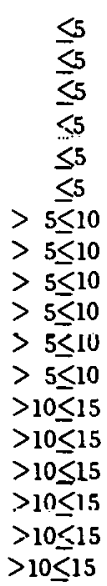

Optimum Number of Contacts
Initial Feed Material

Concentration (\% Pu)

$>15 \leq 25$

$>15 \leq 25$

$>15 \leq 25$

$>15<25$

긴 25

$>15<25$

$>25 \leq 40$

$>25 \leq 40$

$>25 \leq 40$

$>25 \leq 40$

$>35<10$

$>25 \leq 40$

$>40$

$>40$

$>40$

$>40$

$>40$
Initial Solid to Liquid Ratio (g/l)
Optimum Number of Contacts 